\title{
Melatonin treatment in the prevention of postoperative delirium in cardiac surgery patients
}

\author{
Panagiotis Artemiou ${ }^{1}$, Boris Bily ${ }^{1}$, Miroslava Bilecova-Rabajdova ${ }^{2}$, Frantisek Sabol ${ }^{1}$, Pavol Torok $^{3}$, \\ Peter Kolarcik ${ }^{4}$, Adrian Kolesar ${ }^{1}$ \\ ${ }^{1}$ University of P.J. Safarik in Kosice, Medical Faculty, Department of Cardiovascular Surgery, Eastern Slovak \\ Institute for Cardiovascular Diseases, Kosice, Slovakia \\ ${ }^{2}$ University of P.J. Safarik in Kosice, Medical Faculty, Department of Clinical Biochemistry, Kosice, Slovakia \\ ${ }^{3}$ University of P.J. Safarik in Kosice, Medical Faculty, Department of Cardiac Anesthesia, Eastern Slovak Institute \\ for Cardiovascular Diseases, Kosice, Slovakia \\ ${ }^{4}$ University of P.J. Safarik in Kosice, Medical Faculty, Department of Public Health, Kosice, Slovakia
}

Kardiochirurgia i Torakochirurgia Polska 2015; 12 (2): 126-133

\begin{abstract}
Introduction: Post-cardiac surgery delirium is a severe complication. The circadian rhythm of melatonin secretion has been shown to be altered postoperatively.

Aim of the study: It was hypothesized that restoring normal sleeping patterns with a substance that is capable of resynchronizing circadian rhythm such as exogenous administration of melatonin may possibly reduce the incidence of postoperative delirium.

Material and methods: This paper represents a prospective clinical observational study. Two consecutive groups of 250 consecutive patients took part in the study. Group A was the control group and group $B$ was the melatonin group. In group $B$, the patients received prophylactic melatonin treatment. The main objectives were to observe the incidence of delirium, to identify any predictors of delirium, and to compare the two groups based on the delirium incidence.

Results: The incidence of delirium was $8.4 \%$ in the melatonin group vs. $20.8 \%$ in the control group ( $p=0.001)$. Predictors of delirium in the melatonin group were age $(p=0.001)$ and higher EurOSCORE II value $(p=0.001)$. In multivariate analysis, age and EuroSCORE II value $(p=0.014)$ were predictors of postoperative delirium. Comparing the groups, the main predictors of delirium were age $(p=0.001)$, EuroSCORE II value $(p=0.001)$, cardio-pulmonary bypass (CPB) time $(p=0.001)$, aortic crossclamping (ACC) time $(p=0.008)$, sufentanil dose $(p=0.001)$ and mechanical ventilation $(p=0.033)$.

Conclusions: Administration of melatonin significantly decreases the incidence of postoperative delirium after cardiac surgery. Prophylactic treatment with melatonin should be considered in every patient scheduled for cardiac surgery. Key words: melatonin, prevention, delirium, cardiac surgery.
\end{abstract}

\section{Streszczenie}

Wstęp: Majaczenie po zabiegach kardiochirurgicznych jest poważnym powikłaniem. Wykazano, że rytm dobowy wydzielania melatoniny zmienia się pooperacyjnie.

Cel pracy: Weryfikacja hipotezy głoszącej, że występowanie pooperacyjnego majaczenia można zredukować poprzez przywrócenie prawidłowego cyklu snu za pomocą substancji będących w stanie wywołać resynchronizację rytmu dobowego, takich jak melatonina podana egzogennie.

Materiat i metody: W niniejszej pracy przedstawiono prospektywne obserwacyjne badanie kliniczne. W badaniu udział wzięły dwie kolejne grupy liczące po 250 kolejnych pacjentów. Pacjenci w grupie B otrzymywali profilaktycznie melatoninę, podczas gdy grupa A stanowiła grupę kontrolną. Głównym celem była obserwacja występowania majaczenia, identyfikacja jego czynników predykcyjnych oraz porównanie obu grup pod względem występowania majaczenia.

Wyniki: Częstość występowania majaczenia wyniosła 8,4\% w grupie z melatoniną vs $20.8 \%$ w grupie kontrolnej $(p=0,001)$. Czynnikami predykcyjnymi majaczenia $w$ grupie z melatoniną były wiek $(p=0,001)$ oraz wyższy wynik na skali EuroSCORE II $(p=0,001)$. W analizie wielowymiarowej czynnikami predykcyjnymi majaczenia były wiek oraz wartość EuroSCORE II $(p=0,014)$. Porównanie obu grup zaowocowało wykazaniem następujących czynników predykcyjnych majaczenia: wiek $(p=0,001)$, wartość EuroSCORE II ( $p=0,001)$, czas użycia płucoserca $(p=0,001)$, czas poprzecznego zaklemowania aorty $(p=0,008)$, dawka sufentanylu $(p=0,001)$ oraz wentylacja mechaniczna $(p=0,033)$.

Wnioski: Podanie melatoniny znacząco zmniejsza występowanie pooperacyjnego majaczenia po zabiegach kardiochirurgicznych. Profilaktyczne zastosowanie melatoniny powinno rozważyć się u każdego pacjenta, który ma zostać poddany operacji kardiochirurgicznej.

Słowa kluczowe: melatonina, profilaktyka, majaczenie, kardiochirurgia.

Address for correspondence: Boris Bily, MD, Eastern Slovak Institute for Cardiovascular Diseases, 8 Ondavska St., 04011 Kosice, Slovak Republic, phone: +421 910487 461, e-mail: boris_bil@yahoo.co.uk 


\section{Introduction}

Post-cardiac surgery delirium is a severe complication which can develop in any patient during the early postoperative period and is characterized by altered consciousness and global cognitive disturbances. The delirium has been reported to occur in $10 \%$ to $60 \%$ of surgical patients [1]. Moreover, in intensive care unit (ICU), up to $81 \%$ of patients manifest delirium [2].

Melatonin is a neurohormone that is synthesized from tryptophan and secreted by the pineal gland and is released directly into the bloodstream in a circadian pattern governed by the light and dark cycle. It produces hypnotic effects by accelerating sleep initiation and improving sleep maintenance and efficiency. This circadian rhythm of melatonin secretion has been shown to be altered postoperatively, and this may lead to changes in sleeping patterns [3]. Moreover, its plasma levels are decreased after surgery and in hospitalized patients [4].

Delirium and perioperative sleep disturbance are potentially linked, either as predisposing factors or as symptoms of one another.

\section{Aim}

Thus it was hypothesized that restoring normal sleeping patterns with a substance that is capable of resynchronizing circadian rhythm such as exogenous administration of melatonin may possibly reduce the incidence of postoperative delirium. Moreover, synthetic melatonin supplements proved successful when used as a premedication to reduce anxiety and sedate patients preoperatively, with an excellent cognitive profile [5].

The aim of this prospective observational study was to study the effect of melatonin treatment in the prevention of postoperative delirium in cardiac surgery patients.

\section{Material and methods}

In this prospective single center observational non-randomized study the patients were divided into two consecutive groups. The study took place in a tertiary level care facility from September 2012 to July 2013. The first group (group A), which was the control group, included 250 consecutive patients who had various types of cardiac surgery in our institution and were operated on in an elective $(n=183)$ or urgent $(n=67)$ regime. The second group (group B) also included 250 consecutive patients who received prophylactic perioperative melatonin treatment and had various types of cardiac surgery in our institution and were also operated on in an elective $(n=178)$ or urgent $(n=72)$ setting (frequency and representation of the types of operations are presented in Table I). The patients received $5 \mathrm{mg}$ of melatonin (Circadin, Neurim Pharmaceuticals EEC Limited, UK; prolonged-release tablets) the evening before the operation, and the treatment was continued until postoperative day 3. Patients treated on an emergency basis were excluded from the study in both groups (group B - emergent patients could not receive the evening before surgery prophylactic melatonin treatment; group A - the need for a comparable homogeneous group). Of the patients who participated in both groups, medical history and preoperative characteristics (concomitant diseases or risk factors such as hypertension, diabetes mellitus, hypercholesterolemia, smoking, alcoholism, previous psychiatric disease), perioperative details (type of operation, duration of cardiopulmonary bypass and aortic cross-clamp, doses of opiates and benzodiazepines administered during the operation) and postoperative details (duration of mechanical ventilation > 24 hours, ICU and hospital stay) were recorded.

Also the EuroSCORE II value was calculated for all patients in both groups, and they were accordingly categorized into three groups as high, moderate and low risk (low risk < $1.6 \%$, moderate risk $1.6 \%-6.7 \%$, high risk > 6.7\%).

Cardiac surgery, the anesthetic regimen and the postoperative management were standardized.

\section{Ethics}

Ethical approval for this study was provided by the local Ethical Committee on 26/8/2012.

All the study participants provided written informed consent.

\section{Anesthetic technique}

All patients in both groups received premedication of $10 \mathrm{mg}$ oxazepam the evening before surgery and $7.5 \mathrm{mg}$ of midazolam 1 to $2 \mathrm{~h}$ before surgery. Anesthesia was induced by $2.5-5 \mathrm{mg}$, midazolam, $2-2.5 \mathrm{mg} / \mathrm{kg}$ propofol, sufentanil 0.01-0.025 mg and sevoflurane 1-2\%. Tracheal intubation was facilitated by $0.6-1 \mathrm{mg} / \mathrm{kg}$ atracurium. Anesthesia was maintained with sufentanil infusion $0.0005 \mathrm{mg} / \mathrm{kg} / \mathrm{h}$ and sevoflurane $1-2 \%$, while neuromuscular blockade was maintained with the administration of atracurium $50 \mathrm{mg}$ every 40 minutes. No propofol was administered during anesthesia maintenance.

\section{Surgical procedure of cardiopulmonary bypass}

All surgical procedures were performed through median sternotomy. For patients undergoing off-pump surgery, distal anastomoses were performed using a tissue vacuum stabilizer (ACROBAT V, MAQUET Holding $\mathrm{GmbH}$ ). The no-touch aorta technique was used in off-pump surgery. Nasopharyngeal temperature was maintained above $35^{\circ} \mathrm{C}$ and systolic blood pressure was kept at $80 \mathrm{mmHg}$ or higher throughout the procedure.

For patients undergoing on-pump surgery, anticoagulation was achieved with heparin to maintain an activated clotting time above $480 \mathrm{~s}$, and the cardiopulmonary bypass circuit was primed with 1 I of Ringer's Lactate and $250 \mathrm{ml}$ of $20 \%$ mannitol. Mild hypothermia of $34-35^{\circ} \mathrm{C}$ was induced during cardiopulmonary bypass; the pump flow rate was 2.4-2.8 $\mathrm{l} / \mathrm{min} / \mathrm{m}^{2}$, and the mean perfusion pressure was within $70-75 \mathrm{mmHg}$. Hematocrit was maintained within $25-35 \%$. Myocardial protection was achieved with intermit- 
Tab. I. Preoperative, perioperative and postoperative clinical patients' characteristics: comparison of the control group and melatonin group

\begin{tabular}{|c|c|c|c|}
\hline & $\begin{array}{l}\text { Control group } \\
\text { Total }(n=250)\end{array}$ & $\begin{array}{l}\text { Melatonin group } \\
\text { Total }(n=250)\end{array}$ & $P$ value \\
\hline Age (years), mean \pm SD [SEM] & $65.2 \pm 10.3[0.65]$ & $64.3 \pm 10.1[0.64]$ & 0.211 \\
\hline$<50$ & $19(7.6 \%)$ & $17(6.8 \%)$ & \\
\hline $50-70$ & $146(58.4 \%)$ & $165(66.0 \%)$ & \\
\hline$>70$ & $85(34.0 \%)$ & $68(27.2 \%)$ & \\
\hline Men & $171(68.4 \%)$ & $179(71.6 \%)$ & 0.378 \\
\hline Women & 79 (31.6\%) & $71(28.4 \%)$ & \\
\hline Diabetes mellitus & $77(30.8 \%)$ & $84(33.6 \%)$ & 0.502 \\
\hline Arterial hypertension & $229(91.6 \%)$ & $224(89.6 \%)$ & 0.443 \\
\hline Hypercholesterolemia & $187(74.8 \%)$ & $192(76.8 \%)$ & 0.601 \\
\hline Smoking & $88(35.2 \%)$ & $101(40.4 \%)$ & 0.267 \\
\hline Alcoholism & $26(10.2 \%)$ & $13(5.2 \%)$ & 0.030 \\
\hline Psychiatric disorder in the medical history & $22(8.8 \%)$ & $14(5.6 \%)$ & 0.115 \\
\hline EuroSCORE II (\%), mean \pm SD [SEM] & $2.63 \pm 2.65[0.17]$ & $2.86 \pm 2.83[0.18]$ & 0.489 \\
\hline Low risk $<1.6$ & $106(42.4 \%)$ & $92(36.8 \%)$ & \\
\hline Moderate risk 1.6-6.7 & $124(49.6 \%)$ & $137(54.8 \%)$ & \\
\hline High risk > 6.7 & $20(8.0 \%)$ & $21(8.4 \%)$ & \\
\hline \multicolumn{4}{|l|}{ Operation type } \\
\hline CABG & $104(41.6 \%)$ & $120(48.0 \%)$ & 0.524 \\
\hline AVR & $50(20.0 \%)$ & $50(20.0 \%)$ & 0.290 \\
\hline MVR & $20(8.0 \%)$ & $15(6.0 \%)$ & 0.162 \\
\hline $\mathrm{CABG}+\mathrm{AVR}$ & $27(10.8 \%)$ & $18(7.2 \%)$ & 0.363 \\
\hline $\mathrm{CABG}+\mathrm{MVR}$ & $8(3.2 \%)$ & $8(3.2 \%)$ & 1 \\
\hline$A V R+M V R$ & $4(1.6 \%)$ & $3(1.2 \%)$ & 0.146 \\
\hline$A V R+M V R+C A B G$ & $3(1.2 \%)$ & $1(0.4 \%)$ & 1 \\
\hline OPCAB & $32(12.8 \%)$ & $24(9.6 \%)$ & 0.317 \\
\hline Other (ASD, myxoma) & $2(0.8 \%)$ & $11(4.4 \%)$ & 0.002 \\
\hline $\mathrm{ACC}(\mathrm{min})$, mean \pm SD [SEM] & $55.11 \pm 38.61[2.44]$ & $49.47 \pm 30.73[1.94]$ & 0.090 \\
\hline$\leq 60$ & $101(40.4 \%)$ & $183(73.2 \%)$ & \\
\hline$>60$ & $149(59.6 \%)$ & $67(26.8 \%)$ & \\
\hline $\mathrm{CPB}(\mathrm{min})$, mean \pm SD $[\mathrm{SEM}]$ & $72.90 \pm 45.46[2.87]$ & $66.93 \pm 36.87[2.33]$ & 0.001 \\
\hline$\leq 120$ & $232(92.8 \%)$ & $228(91.2 \%)$ & \\
\hline$>120$ & $18(7.2 \%)$ & $22(8.8 \%)$ & \\
\hline Sufentanil (mg), mean \pm SD [SEM] & $0.15 \pm 0.03[0.002]$ & $0.15 \pm 0.03[0.002]$ & 0.286 \\
\hline$\leq 0.15$ & $178(71.2 \%)$ & $190(76.0 \%)$ & \\
\hline$>0.15$ & $72(28.8 \%)$ & $60(24.0 \%)$ & \\
\hline Benzodiazepines (mg), mean \pm SD [SEM] & $4.73 \pm 2.86[0.18]$ & $3.52 \pm 3.30[0.21]$ & 0.116 \\
\hline$\leq 5$ & $217(86.8 \%)$ & $228(91.2 \%)$ & \\
\hline$>5$ & $33(13.2 \%)$ & $22(8.8 \%)$ & \\
\hline Mechanical ventilation (hours), mean \pm SD $[S E M]$ & $3.70 \pm 2.39[0.15]$ & $3.85 \pm 3.57[0.22]$ & 0.033 \\
\hline ICU stay (days), mean \pm SD [SEM] & $4.62 \pm 3.47[0.22]$ & $4.22 \pm 2.99[0.19]$ & 0.001 \\
\hline$\leq 3$ & $126(50.4 \%)$ & $125(50.0 \%)$ & \\
\hline$>3$ & $124(49.6 \%)$ & $125(50.0 \%)$ & \\
\hline Hospitalization (days), mean \pm SD [SEM] & $10.84 \pm 6.85[0.43]$ & $9.54 \pm 3.89[0.25]$ & 0.001 \\
\hline$\leq 10$ & $180(72.0 \%)$ & $197(78.8 \%)$ & \\
\hline$>10$ & $70(28.0 \%)$ & $53(21.2 \%)$ & \\
\hline
\end{tabular}

SD - standard deviation, SEM - standard error of the mean, CABG - coronary artery bypass graft surgery, AVR - aortic valve replacement, MVR - mitral valve replacement, OPCAB - off-pump coronary artery bypass, ASD - atrial septal defect, ACC - aortic cross-clamping, CPB - cardio-pulmonary bypass, ICU - intensive care unit 
tent blood-enriched cold cardioplegic solution (St. Thomas cardioplegic solution at $3-6^{\circ} \mathrm{C}$ ) using a blood to crystalloid ratio of $5: 1$. Fractional concentration of inspired oxygen was adjusted to keep oxygen partial pressure within 150-250 $\mathrm{mmHg}$, and gas flow was adjusted to maintain arterial carbon dioxide tension within $35-40 \mathrm{mmHg}$ without temperature correction ( $\alpha$-stat).

After all distal anastomoses were completed, the aortic cross-clamp was removed and proximal anastomoses were then performed by means of a single side-clamp on the aorta.

\section{Postoperative management}

After surgery, all the patients were admitted to the cardiovascular ICU, where a standard protocol was implemented for sedation, analgesia and management of mechanical ventilation. Patients were extubated according to the following criteria: responsive and cooperative, $\mathrm{pO}_{2}$ of 10-11 $\mathrm{kPa}$ and oxygenation index of $\mathrm{pO}_{2} / \mathrm{FiO}_{2}>300$. In the ICU patients were sedated with propofol until extubation. Analgesia was provided with intravenous morphine infusion at $2 \mathrm{mg} / \mathrm{h}$, Algifen (metamizole, pitofenone, fenpiverinium, Zentiva Group a.s. Czech Rep.) 2.5 g every 8 hours and intravenous tramadol 100 mg every 8 hours.

\section{Delirium assessment}

Delirium was assessed with the CAM-ICU (Confusion Assessment Method for the Intensive Care Unit) every $12 \mathrm{~h}$ postoperatively. The CAM-ICU allows the monitoring of delirium in both ventilated and extubated patients. It is based on the Diagnostic and Statistical Manual of Mental Disorders criteria and includes a 4-step algorithm. The patient is determined to be delirious (CAM-positive) if he or she manifests standard features for delirium.

All cardiovascular ICU nurses were educated and well trained in the application of the CAM-ICU in both ventilated and non-ventilated patients.

The level of sedation (level of arousal) was assessed by means of the Richmond Agitation Sedation Scale (RASS).

\section{Statistical analysis}

Data are given as mean value \pm standard deviation (SD) and standard error of the mean (SEM). Categorical variables are presented as numbers of patients (percentage). A univariate analysis was performed to identify perioperative risk factors in both groups associated with delirium using chi-square analyses or Fisher's exact test. Different cut-off points for continuous variables were examined to determine the best association with delirium. Odds ratios (OR) were calculated to indicate the effect size of perioperative risk factors on delirium. Variables associated with outcome with a $p$ value $<0.05$ in the univariate analyses and variables considered clinically significant were entered into a multiple logistic regression model for delirium in order to identify independent risk factors. This was performed using the stepwise logistic regression technique.
Finally, groups A and B were statistically matched, analyzed and compared.

For statistical analysis the SPSS software version 22 (SPSS Inc., Chicago, IL, USA) was used.

\section{Results}

The study included two groups, each with 250 eligible patients. Delirium developed in 52 (20.8\%) patients from group A and 21 (8.4\%) patients from group B, with the difference in incidence of delirium between the groups being statistically significant $(p=0.001)$. The patients developed only hyperactive delirium. No hypoactive or mixed types of delirium were observed.

The preoperative and perioperative clinical patients' characteristics of the two groups and the comparison of groups are shown in Table I.

Patients with postoperative delirium in both groups had a longer stay in the ICU ( $p<0.0001, p=0.001$ respectively) and longer total duration of hospitalization $(p<0.0001$, $p=0.002$ ). However, the ICU stay is not a predictor of postoperative delirium ( $p=0.534$ ) in the control group.

Univariate analysis of the variables of group A confirmed that older age $(p<0.0001)$, a higher EuroSCORE II value $(p<0.0001)$, longer cardio-pulmonary bypass (CPB) time $(p<0.0001)$, longer aortic cross-clamping (ACC) time $(p<0.0001)$, and sufentanil dose $(p=0.010)$ were strongly independently associated with postoperative delirium.

In multivariate analysis of the variables of group $A$, age ( $p<0.001)$, EuroSCORE II value $(p<0.001)$, CPB and ACC time $(p<0.05)$, sufentanil dose $(p<0.001)$ and the coronary artery bypass graft surgery (CABG) type of operation $(p<0.001)$ are all predictors of postoperative delirium development.

Univariate analysis of the variables of group B confirmed that only older age $(p=0.001)$ and a higher EuroSCORE II value $(p=0.001)$ were strongly associated with the development of delirium. Concerning CPB time $>120 \mathrm{~min}$, it was shown to be a weak predictor for developing postoperative delirium $(p=0.097)$. The results showed that the administration of melatonin reduced the predictive effect of CPB, ACC time and sufentanil dose in the development of postoperative delirium.

In group A, patients who had a CPB time more than 120 min had a 15 times higher risk for developing postoperative delirium. Also, the longer the ACC time, the higher was the risk for developing postoperative delirium. Finally, the higher the sufentanil dose (the patients were receiving a fixed dose per kg per minute), the higher was the risk for developing postoperative delirium. From this analysis we can see that certain variables such as CPB and ACC time and sufentanil dose are linked to a common parameter, time; so we can infer that the longer the operation lasts, the higher is the risk for developing postoperative delirium.

In group B, administration of melatonin in the univariate analysis eliminated the parameter of time in the development of postoperative delirium. 
Concerning benzodiazepine administration, it was shown in group A to be an intermediate predictor for developing postoperative delirium $(p=0.055)$ in univariate analysis, whereas in group B it was shown not to be a predictor for the development of postoperative delirium ( $p=0.809)$.

Concerning the type of surgery only in group $A, C A B G$ was shown to be associated with the incidence of postoperative delirium $(p=0.010)$.

In group $B$, in multivariate analysis age and EuroSCORE II were shown to be predictors of postoperative delirium development $(p=0.014)$.

Table II shows the univariate analysis of the variables in group A, Table III shows the univariate analysis of the variables in group $B$, and Table IV shows the multivariate analysis of both groups.

After matching, the two groups were found to be comparable. The only variable that could not be match was consumption of alcohol, but the number of patients was low so it could not have any effect on the results. The comparison of the two groups is shown in Table I.

After comparison of the two groups, older age ( $p=$ $0.001)$, higher EuroSCORE II ( $p=0.001)$, CABG type of operation ( $p=0.003)$ and CABG and combined valve operations ( $p=0.018, p=0.010$ respectively) were all confirmed to be associated with an increased risk for the development of postoperative delirium. Perioperative predictors connected with the operative time, such as CPB time $(p=0.001)$, ACC time $(p=0.008)$, and sufentanil dose $>0.15 \mathrm{mg}(p=0.001)$, were also associated with an increased risk for the development of postoperative delirium. Moreover, increased ventilation time $(p=0.033)$ was also associated with postoperative delirium. Finally, patients who suffered from delirium had a prolonged ICU stay $(p=0.001)$ and hospitalization time $(p=0.001)$.

The statistical comparison analysis of the variables of both groups based on the incidence of postoperative delirium is shown in Table $\mathrm{V}$.

The hospital mortality in each group of patients was $1.6 \%$.

\section{Discussion}

In our study the reduction in the incidence of postoperative delirium between the two compared groups was statistically significant. Other authors have published similar results. Sultan SS [6] found in his study of three hundred patients scheduled for hip arthroplasty that only preoperative melatonin administration succeeded significantly in decreasing the incidence of postoperative delirium to $9.43 \%$. Recently, a study concluded that low-dose melatonin in elderly medical patients admitted to the emergency department decreases the risk of delirium [7].

Tab. II. Univariate analysis of variables in control group

\begin{tabular}{|c|c|c|c|c|c|c|c|}
\hline \multirow[t]{2}{*}{ Variable } & \multirow[t]{2}{*}{$n$} & \multirow[t]{2}{*}{$\begin{array}{l}\text { Delirium } \\
n(\%)\end{array}$} & \multirow[t]{2}{*}{$\begin{array}{c}\text { No delirium } \\
n(\%)\end{array}$} & \multirow[t]{2}{*}{$\begin{array}{l}\text { Sig. } \\
P \text { value }\end{array}$} & \multirow[t]{2}{*}{$\begin{array}{c}\operatorname{Exp}(B) \\
O R\end{array}$} & \multicolumn{2}{|c|}{$\begin{array}{c}95 \% \mathrm{Cl} \\
\text { For } \operatorname{Exp}(\mathrm{B}) \mathrm{OR}\end{array}$} \\
\hline & & & & & & Lower & Upper \\
\hline Age (years) & 250 & $52(20.8)$ & $198(79.2)$ & $<0.0001$ & 1.090 & 1.048 & 1.133 \\
\hline Gender & 250 & 52 & 198 & 0.616 & 0.842 & 0.431 & 1.646 \\
\hline EuroSCORE II & 250 & $52(20.8)$ & 198 (79.2) & $<0.0001$ & 1.348 & 1.187 & 1.153 \\
\hline D. mellitus & 77 & $21(27.3)$ & $56(72.7)$ & 0.991 & 1.706 & 0.904 & 3.217 \\
\hline Hypertension & 229 & 49 (21.4) & 180 (78.6) & 0.441 & 1.642 & 0.465 & 5.805 \\
\hline Hypercholest. & 187 & $36(19.3)$ & $151(80.7)$ & 0.309 & 0.705 & 0.359 & 1.383 \\
\hline Smoking & 88 & $13(14.4)$ & $75(85.6)$ & 0.082 & 0.542 & 0.272 & 1.082 \\
\hline Alcoholism & 26 & $5(19.2)$ & $21(80.8)$ & 0.827 & 0.892 & 0.319 & 2.490 \\
\hline Psych. disease & 22 & $2(9.1)$ & $20(90.9)$ & 0.171 & 0.354 & 0.080 & 1.566 \\
\hline ACC time (min) & 250 & & & 0.003 & 1.010 & 1.003 & 1.017 \\
\hline$>60$ & 149 & $36(24.2)$ & $113(75.8)$ & $<0.001$ & & & \\
\hline \multicolumn{8}{|l|}{ CPB time (min) } \\
\hline$>120$ & 18 & $10(55.6)$ & $8(44.4)$ & $<0.0001$ & 15.188 & 3.749 & 61.626 \\
\hline Sufentanil d. (mg) & 250 & $52(20.8)$ & $198(79.2)$ & $<0.0101$ & 12.419 & 16.649 & 92.644 \\
\hline Benzo. d. (mg) & 250 & $52(20.8)$ & $198(79.2)$ & 0.055 & 1.120 & 0.998 & 1.257 \\
\hline ICU stay (days) & 250 & $52(20.8$ & $198(79.2)$ & $<0.0001$ & 1.256 & 1.137 & 1.387 \\
\hline Hosp. stay (days) & 250 & $52(20.8)$ & $198(79.2)$ & $<0.0001$ & 1.112 & 1.056 & 1.172 \\
\hline Operation type & 250 & $52(20.8)$ & $198(79.2)$ & & & & \\
\hline OPCAB & 32 & $6(18.7)$ & $26(81.3)$ & 0.823 & 0.897 & 0.348 & 2.317 \\
\hline CABG & 104 & 20 (19.2) & $84(80.8)$ & 0.010 & 2.427 & 1.238 & 4.760 \\
\hline Valve comb., OS & 114 & $26(29.6)$ & $88(70.4)$ & 0.460 & 1.269 & 0.674 & 2.390 \\
\hline
\end{tabular}

sig. - significant, $\operatorname{Exp}(\mathrm{B})$ - coefficient, OR - odds ratio, Cl - confidence interval, D. - diabetes, Hypercholest. - hypercholesterolemia, Psych. - psychiatric, ACC aortic cross-clamping, CPB - cardio-pulmonary bypass, d. - dose, Benzo. - benzodiazepine, ICU - intensive care unit, Hosp. - hospitalization, OPCAB - off-pump coronary artery bypass, CABG - coronary artery bypass graft surgery, comb. - combined, OS - other surgery 
Tab. III. Univariate analysis of variables in melatonin group

\begin{tabular}{|c|c|c|c|c|c|c|c|}
\hline \multirow[t]{2}{*}{ Variable } & \multirow[t]{2}{*}{$n$} & \multirow[t]{2}{*}{$\begin{array}{l}\text { Delirium } \\
n(\%)\end{array}$} & \multirow[t]{2}{*}{$\begin{array}{c}\text { No delirium } \\
n(\%)\end{array}$} & \multirow[t]{2}{*}{$\begin{array}{c}\text { Sig. } \\
\text { P value }\end{array}$} & \multirow[t]{2}{*}{$\begin{array}{c}\operatorname{Exp}(B) \\
\text { OR }\end{array}$} & \multicolumn{2}{|c|}{$\begin{array}{c}95 \% \mathrm{Cl} \\
\text { For } \operatorname{Exp}(\mathrm{B}) \mathrm{OR} \\
\end{array}$} \\
\hline & & & & & & Lower & Upper \\
\hline Age (years) & 250 & $21(8.4)$ & 229 (91.6) & 0.001 & 1.115 & 1.050 & 1.184 \\
\hline Gender & 250 & 52 & 198 & 0.334 & 1.731 & 0.561 & 5.340 \\
\hline EuroSCORE II & 250 & $21(8.4)$ & 228 (91.6) & 0.001 & 1.353 & 1.174 & 1.559 \\
\hline D. mellitus & 84 & $5(2.3)$ & 79 (94.7) & 0.319 & 1.697 & 0.599 & 4.803 \\
\hline Hypertension & 223 & $20(9.0)$ & 203 (91.0) & 0.389 & 0.406 & 0.052 & 3.157 \\
\hline Hypercholest. & 191 & $18(9.4)$ & $173(90.6)$ & 0.315 & 0.524 & 0.149 & 1.847 \\
\hline Smoking & 100 & $11(11.0)$ & $89(89.0)$ & 0.237 & 0.582 & 0.237 & 1.427 \\
\hline Alcoholism & 13 & $2(15.4)$ & $11(84.6)$ & 0.364 & 0.482 & 0.099 & 2.333 \\
\hline Psych. disease & 22 & $2(9.1)$ & $20(90.9)$ & 0.171 & 0.354 & 0.080 & 1.566 \\
\hline \multicolumn{8}{|l|}{ ACC time (min) } \\
\hline$>60$ & 138 & $13(9.4)$ & $125(90.6)$ & $<0.533$ & & & \\
\hline \multicolumn{8}{|l|}{ CPB time (min) } \\
\hline$>120$ & 22 & $4(18.2)$ & $18(81.8)$ & 0.097 & 0.364 & 0.111 & 1.198 \\
\hline Sufentanil d. (mg) & 250 & $22(8.4)$ & $228(91.6)$ & 0.339 & 5.838 & 0.140 & 2.449 \\
\hline Benzo. d. (mg) & 250 & $22(8.4)$ & $228(91.6)$ & 0.809 & 1.017 & 0.890 & 1.161 \\
\hline ICU stay & 82 & 7 (13.5) & $45(86.5)$ & 0.149 & 0.492 & 0.188 & 1.290 \\
\hline Hosp. stay (days) & 250 & $22(21.3)$ & $228(78.7)$ & 0.002 & 0.145 & 0.042 & 0.505 \\
\hline \multicolumn{8}{|l|}{ Operation type } \\
\hline OPCAB & 24 & $1(4.3)$ & $23(95.8)$ & 0.441 & 2.244 & 0.288 & 2.320 \\
\hline CABG & 14 & $2(14.3)$ & $12(85.7)$ & 0.119 & 0.438 & 0.155 & 1.387 \\
\hline Valve comb., OS & 250 & $98(38.6)$ & $153(61.4)$ & 0.672 & 0.823 & 0.333 & 1.172 \\
\hline
\end{tabular}

sig. - significant, Exp(B) - coefficient, OR - odds ratio, Cl - confidence interval, D. - diabetes, Hypercholest. - hypercholesterolemia, Psych. - psychiatric, ACC aortic cross-clamping, CPB - cardio-pulmonary bypass, d. - dose, Benzo. - benzodiazepine, ICU - intensive care unit, Hosp. - hospitalization, OPCAB - off-pump coronary artery bypass, CABG - coronary artery bypass graft surgery, comb. - combined, OS - other surgery

Tab. IV. Multivariate analysis of variables of both groups

\begin{tabular}{lcccc} 
Variable & \multicolumn{2}{c}{ Control group } & \multicolumn{2}{c}{ Melatonin group } \\
\cline { 2 - 5 } Age & OR $(95 \% \mathrm{Cl})$ & P value & OR (95\% CI) & P value \\
\hline EuroSCORE II & $1.106(1.061-1.155)$ & $<0.050$ & $0.985(0.972-0.997)$ & 0.014 \\
\hline CPB time & $1.331(1.171-1.514)$ & $<0.050$ & $0.985(0.972-0.997)$ & 0.014 \\
\hline ACC time & $1.009(1.002-1.016)$ & $<0.050$ & & \\
\hline Sufentanil d. & $1.010(1.002-1.019)$ & $<0.050$ & & \\
\hline CABG & $5.657(2.159-14.821)$ & $<0.001$ & & \\
\hline
\end{tabular}

$\mathrm{OR}$ - odds ratio, $\mathrm{Cl}$ - confidence interval, CPB - cardio-pulmonary bypass, ACC - aortic cross-clamping, d. - dose, CABG - coronary artery bypass graft surgery

In the melatonin group only older age and a higher EuroSCORE II value were shown to be strongly associated with the development of delirium. The results showed that the administration of melatonin reduced the predictive effects of CPB, ACC time and the sufentanil dose in the development of postoperative delirium.

After matching, the two groups were found to be comparable. After comparison of the two groups, older age, higher EuroSCORE II, CABG type of operation and CABG combined with valve operations were all confirmed to be associated with an increased risk for the development of postoperative delirium. Perioperative predictors connected with the operative time, such as CPB time, ACC time, and sufentanil dose $>0.15 \mathrm{mg}$, were also associated with an increased risk for the development of postoperative delirium.

Age has consistently been reported as a predictor of postoperative delirium [8]. Moreover, concerning the EuroSCORE value, Osse et al. [9] found that a EuroSCORE value greater than 6 was associated with the occurrence of postoperative delirium.

Another two intraoperative predictors found in our study to be associated with postoperative delirium are longer CPB and ACC times. Other reports published in the literature have similar results. Andrejaitiene et al. [10] found that ACC time $>68 \mathrm{~min}$ is associated with the development 
Tab. V. Statistical comparison analysis of variables in both groups based on the incidence of postoperative delirium

\begin{tabular}{|c|c|c|c|c|c|c|c|c|}
\hline \multirow[t]{2}{*}{ Variable } & \multirow[t]{2}{*}{$n$} & \multicolumn{2}{|c|}{ Delirium, $n(\%)$} & \multirow[t]{2}{*}{$\begin{array}{c}\text { No delirium, } \\
n(\%)\end{array}$} & \multirow[t]{2}{*}{$\begin{array}{c}\text { Sig. } \\
P \text {-value }\end{array}$} & \multirow{2}{*}{$\begin{array}{l}\text { Exp } \\
\text { (B) } \\
\text { OR }\end{array}$} & \multicolumn{2}{|c|}{$\begin{array}{l}95 \% \mathrm{Cl} \text { for } \\
\operatorname{Exp}(\mathrm{B}) \mathrm{OR} \\
\end{array}$} \\
\hline & & $\begin{array}{l}\text { Control } \\
\text { group }\end{array}$ & $\begin{array}{l}\text { Melatonin } \\
\text { group }\end{array}$ & & & & Lower & Upper \\
\hline Incidence & & $20.8 \%$ & $8.4 \%$ & & 0.001 & & & \\
\hline Age (years) & & & & & 0.001 & 1.098 & 1.063 & 1.134 \\
\hline Gender & & & & & 0.432 & 1.252 & 0.714 & 2.197 \\
\hline EuroSCORE II & & & & & 0.001 & 1.314 & 1.203 & 1.435 \\
\hline D. mellitus & & & & & 0.516 & 1.188 & 0.706 & 2.000 \\
\hline Hypertension & & & & & 0.218 & 1.942 & 0.675 & 5.583 \\
\hline Hypercholest. & & & & & 0.709 & 0.898 & 0.508 & 1.584 \\
\hline Smoking & & & & & 0.353 & 0.779 & 0.461 & 1.319 \\
\hline Alcoholism & & & & & 0.829 & 1.101 & 0.460 & 2.637 \\
\hline Psych. disease & & & & & 0.416 & 0.638 & 0.215 & 1.888 \\
\hline \multicolumn{9}{|l|}{ Operation type } \\
\hline$\overline{C A B G}$ & & & & & 0.003 & 2.385 & 1.355 & 4.198 \\
\hline OPCAB & & & & & 0.547 & 0.771 & 0.331 & 1.798 \\
\hline AVR & & & & & 0.409 & 1.248 & 0.737 & 2.112 \\
\hline$\overline{M V R}$ & & & & & 0.132 & 1.695 & 0.852 & 3.372 \\
\hline $\mathrm{AVR}+\mathrm{MVR}$ & & & & & 0.248 & 1.342 & 0.815 & 2.208 \\
\hline$C A B G+A V R$ & & & & & 0.018 & 2.698 & 1.186 & 6.138 \\
\hline CABG + MVR & & & & & 0.010 & 2.224 & 1.210 & 4.090 \\
\hline$\overline{C A B G}+\mathrm{AVR}+\mathrm{MVR}$ & & & & & 0.010 & 2.224 & 1.210 & 4.090 \\
\hline CPB time & & & & & 0.001 & 1.010 & 1.004 & 1.015 \\
\hline ACC time & & & & & 0.008 & 1.009 & 1.002 & 1.016 \\
\hline Sufentanil d. $(\mathrm{mg})>0.15$ & & & & & 0.001 & 5.679 & 2.591 & 12.446 \\
\hline Benzodiaz. & & & & & 0.142 & 0.936 & 0.856 & 1.023 \\
\hline M. vent. & & & & & 0.033 & 1.078 & 1.006 & 1.155 \\
\hline ICU stay & & & & & 0.001 & 1.234 & 1.145 & 1.330 \\
\hline Hosp. stay & & & & & 0.001 & 1.107 & 1.060 & 1.155 \\
\hline
\end{tabular}

sig. - significant, Exp(B) - coefficient, OR - odds ratio, Cl - confidence interval, D. - diabetes, Hypercholest. - hypercholesterolemia, Psych. - psychiatric, CABG coronary artery bypass graft surgery, OPCAB - off-pump coronary artery bypass, AVR - aortic valve replacement, MVR - mitral valve replacement, CPB - cardio-pulmonary bypass, ACC - aortic cross-clamping, d. - dose, Benzodiaz. - benzodiazepine, M. vent. - mechanical ventilation, ICU - intensive care unit, Hosp. - hospitalization

of delirium. Similar results are reported by other authors, finding that increased CPB times are associated with the development of postoperative delirium [11].

Furthermore, it was shown that the higher the sufentanil dose (the patients in our study were receiving a fixed dose per kg per minute), the higher is the risk for developing postoperative delirium. The sufentanil dose is linked with time, so the longer the duration of the operation, the higher is the sufentanil dose, and the higher is the risk for developing postoperative delirium. This association has also been investigated by other authors. Burkart et al. [12] found that an increasing dose of fentanyl administered intraoperatively appeared to be a risk factor for postoperative delirium.

Concerning the benzodiazepine dose, it was also found in the control group to be an intermediate predictor for developing postoperative delirium, whereas in the melatonin group it was not a predictor of postoperative delirium. Pan- dharipande et al. [13] also reported that exposure to benzodiazepines is one of the strongest modifiable risk factors for postoperative delirium development. In our study the patients developed only the hyperactive type of delirium. McPherson et al. [14] found that patients who received benzodiazepines and were restrained after heart surgery had the hypoactive type of delirium. Avoiding chemical restraint via the use of benzodiazepines or the use of physical restraint via the use of benzodiazepines or the use of physical restraint devices and as much as possible early mobilization could be an effective preventive strategy to decrease the development of postoperative delirium. In our department patients with an uncomplicated postoperative course were usually mobilized on the $1^{\text {st }}$ or $2^{\text {nd }}$ postoperative day.

Concerning the type of the operation, in our study only $C A B G$ and $C A B G$ combined with valve operation were associated with the development of postoperative delirium. Other authors have also reported a higher incidence of de- 
lirium in patients undergoing valve replacement and combined surgery with valve replacement and CABG compared with patients undergoing isolated coronary artery bypass graft surgery [15]. The reason for this according to the authors may be the embolization of air which is trapped within the cardiac chambers during the valve replacement surgery. Concerning our study, the relatively small sample size of valve replacement patients compared with the CABG patient sample could be responsible for the fact that in our patient population CABG surgery alone or combined with valve surgery, and not valve surgery, is associated with the development of postoperative delirium.

In our study, the time frame for early post-cardiac surgery delirium is defined as 2-6 days after the operation, since delirium diagnosed on the first or after the sixth day following cardiac surgery might not be directly linked to the surgery [16].

In the literature there are not many studies that examine the role of exogenous melatonin in the prevention of postoperative delirium, especially in the group of patients after cardiac surgery which we examined, and this may be considered one of the strengths of this study. Also in the melatonin group of patients, we tried to identify potential predictors of postoperative delirium.

Melatonin administration significantly decreased the overall incidence of postoperative delirium and may decrease the effect of various postoperative delirium predictors. Other perioperative strategies should be developed, despite the positive effect of the melatonin treatment, in order to further reduce the incidence of postoperative delirium in cardiac surgery patients.

The study has some limitations. Firstly, this is a prospective observational study. A more powerful, randomized, placebo-controlled, double-blind trial should be performed in order to confirm the results of this study. Secondly, we did not perform baseline psychiatric and cognitive screening tests as preoperative mental disorders are strong predictors of postoperative delirium. Any psychiatric disorders that were examined in our study were obtained from the medical history of the patient, and their incidence may have been underestimated. Thirdly, the CAM-ICU assessment was performed in the cardiovascular ICU and was not extended to the cardiac surgical floor. As a result, our findings can only be applied to early postoperative delirium.

\section{Conclusions}

The administration of melatonin significantly decreases the incidence of postoperative delirium after cardiac surgery and decreases the effect of various risk factors that are found in patients who did not have melatonin treatment. Even after melatonin treatment, risk factors such as age, EuroSCORE II value, CPB and ACC time, sufentanil dose, ventilation time and operation type may increase to a lesser degree the risk of postoperative delirium. Other perioperative strategies should be developed, in order to further reduce the incidence of postoperative delirium in cardiac surgery patients. Prophylactic treatment with exogenous melatonin should be considered in every patient scheduled for cardiac surgery.

\section{Acknowledgements}

This paper was orally presented at the 1st World Meeting of the Hellenic Cardiothoracic Diaspora in Athens, 20-22 November 2014.

\section{Dislocure}

Authors report no conflict of interest.

\section{References}

1. Norkiene I, Ringaitiene D, Misiuriene I, Samalavicius R, Bubulis R, Baublys A, Uzdavinys $G$. Incidence and precipitating factors of delirium after coronary artery bypass grafting. Scan Cardiovasc J 2007; 41: 212-217.

2. Afonso A, Scurlock C, Reich D, Raikhelkar J, Hossain S, Bodian C, Krol M, Flynn B. Predictive model for postoperative delirium in cardiac surgical patients. Semin Cardiothorac Vasc Anesth 2010; 14: 212-217.

3. Dispersyn G, Pain L, Challet E, Touitou Y. General anesthetics effects on circadian temporal structure: an update. Chronobiol Int 2008; 25: 835-850.

4. Cronin AJ, Keifer JC, Davies MF, King TS, Bixler EO. Melatonin secretion after surgery. Lancet 2000; 356: 1244-1245.

5. Caumo W, Torres F, Moreira NL, Auzani JA, Monteiro CA, Londero G, Ribeiro DF, Hidalgo MP. The clinical impact of preoperative melatonin on postoperative outcomes in patients undergoing abdominal hysterectomy. Anesth Analg 2007; 105: 1263-1271.

6. Sultan SS. Assessment of role of perioperative melatonin in prevention and treatment of postoperative delirium after hip arthroplasty under spinal anesthesia in the elderly. Saudi J Anaesth 2010; 4: 169-173.

7. Al-Alma T, Brymer C, Gutmanis I, Woolmore-Goodwin SM, Esbaugh J, Dasgupta M. Melatonin decreases delirium in elderly patients: a randomized, placebo-controlled trial. Int J Geriatr Psychiatry 2011; 26: 687-694.

8. Kazmiersky J, Kowman M, Banach M, Fendler W, Okonski P, Banys A, Jaszewski R, Rysz J, Mikhailidis DP, Sobow T, Kloszewska I; IPDACS Study. Incidence and predictors of delirium after cardiac surgery. Results from the IPAC study. J Psychom Res 2010; 69: 179-185.

9. Osse RJ, Fekkes D, Tulen JH, Wierdsma AI, Bogers AJ, van der Mast RC, Hengeveld MW. High preoperative plasma neopterin predicts delirium after cardiac surgery in older patients. J Am Geriatr Soc 2012; 60: 661-668.

10. Andrejaitiene J, Sirviskas E. Early post-cardiac surgery delirium risk factors. Perfusion 2011; 27: 105-112.

11. Guenther U, Theuerkauf N, Fromman I, Brimmers K, Malik R, Stori S, Scheidemann M, Putensen C, Popp J. Predisposing and precipitating factors of delirium after cardiac surgery. A prospective observational cohort study. Ann Surg 2013; 257: 1160-1167.

12. Burkhart CS, Dell-Kuster S, Gamberini M, Moeckli A, Grapow M, Filipovic M, Seeberger MD, Monsch AU, Strebel SP, Steiner LA. Modifiable and nonmodifiable risk factors for postoperative delirium after cardiac surgery with cardiopulmonary bypass. J Cardiothorac Vasc Anesth 2012; 4: 555-559.

13. Pandharipande P, Cotton BA, Shintani S, Thompson J, Pun BT, Morris JA Jr, Dittus R, Ely EW. Prevalence and risk factors for development of delirium in a surgical and trauma intensive care unit patients. J Trauma 2008; 65: 34-41.

14. MCPherson JA, Wagner CE, Boehm LM, Hall JD, Johnson DC, Miller LR, Burns KM, Thompson JL, Shintani AK, Ely EW,Pandharipande PP. Delirium in the cardiovascular ICU: exploring modifiable risk factors. Crit Care Med 2013; 41: 405-413.

15. Hudetz JA, Igbal Z, Gandhi SD, Patterson KM, Byrne AJ, Pagel PS. Postoperative delirium and short-term cognitive dysfunction occur more frequently in patients undergoing valve surgery with or without coronary artery bypass graft surgery compared with coronary artery bypass graft surgery alone: results of a pilot study. J Cardiothorac Vasc Anesth 2011; 25: 811-816.

16. Bucerius J, Gummert JF, Borger MA, Walther T, Doll N, Falk V, Schmitt DV, Mohr FW. Predictors of delirium after cardiac surgery delirium: effect of beating-heart (off-pump) surgery. J Thorac Cardiovasc Surg 2004; 27: 57-64. 